Open Access

\title{
Correction to: Big data management skills: accurate measurement
}

Elspeth McKay ${ }^{1 *}$ and Marlina Binti Mohamad²

* Correspondence: elspeth.mckay@rmit.edu.au ${ }^{1}$ RMIT University, School of Business Information Technology and Logistics, GPO Box 2476, Melbourne, Victoria 3000, Australia Full list of author information is available at the end of the article

\section{Correction}

Owing to an unfortunate mistake in typesetting, in the original publication of this article (McKay \& Mohamad, 2018), the citation and legend of some figures were incorrectly displayed. Besides, anonymous information was embedded in the article by mistake after double blind peer reviewing. We list the errors and corrections below:

Figures citation errors and corrections:

\begin{tabular}{ll}
\hline Figures citation upon publication & Figures citation upon correcting \\
T1 Fig. 3 & T1 Fig. 4 \\
T2 Fig. 4 & T2 Fig. 5 \\
Fig. 5 & Fig. 6 \\
Figure 6 & Figure 3 \\
Fig. 3 & Fig. 4 \\
Fig. 4 & Fig. 5 \\
\hline
\end{tabular}

Figures legend errors and corrections:

Figures legend upon publication

Fig. 3 Text-plus-textual metaphor (T1) —repetition programming logic (Anonymous 2000a). This figure represents a textual metaphor for a 'do while loop'

Fig. 4 Text-plus-graphical metaphor (T2)—repetition programming logic (Anonymous 2000a). This figure represents an example of a text-plus-graphical metaphor for a 'do while loop'

Fig. 5 QUEST variable map (Anonymous 2000a). This figure shows how the QUEST estimate develops a unidimensional(logit) scale (- 3.0 to 1.0) with equal intervals along each axis as it measures participants'performances and test items together. The $x^{\prime}$ s on the left hand side of the figure represent an individual participant's performance with the total number of participants being 195. On the right hand side of the figure is the difficulty rating of each test item's performance (partial credit scored test items have multiple entries: 8.1, 8.2 and 9.3, 20.2)
Figures legend upon correcting

Fig. 3 Common expository instructional format (McKay 2000a p.163)

This figure represents an example of an instructional strategy that provides key

information of a programming control flow statement - known as a 'do while loop.' It is showing the testing condition and the procedure for dealing with a condition that has become false.

Fig. 4 Text-plus-textual metaphor (T1) - repetition programming logic (McKay, 2000a p.165)

This figure represents a textual metaphor for a 'do while loop.'

Fig. 5 Text-plus-graphical metaphor (T2) - repetition programming logic (McKay, 2000a p.165)

This figure represents an example of a text-plus-graphical metaphor for a 'do while loop.' 
Fig. 6 QUEST fit map (Anonymous 2000a). This figure shows the fit statistics (listed horizontally .56 to 1.40 is the infit mean square); the asterisks represent the magnitude of the fit statistic for the test item on the same line. The test items that fall between the two vertical dotted lines (thresholds .77 to 1.30) are considered acceptable; test items to the left overfit (see test item 34), indicating duplication or having limited contribution. Underfit test items to the right of the threshold lines, measure something else and need rewording

Fig. 7 Relative distribution - four groups (Anonymous 2000a). This figure shows the relative distribution of the four-instructional treatment/gender groups (treatment 1-textual metaphor and treatment 2-graphical metaphors). Females given the graphical metaphors achieved the highest post-test distribution. Females with the textual metaphor format had the lowest distribution. The two male groupings had similar distributions, resting between the two female distributions

Fig. 8 First screen of web-mediated instructional module (Anonymous 2012a). This figure shows the opening web-mediated instructional system's screen display including how to navigate the instructional content and guidance on how to work through the instructional modules, (knowledge) navigation buttons or hyperlinks, and menu positioning relating to the current topic and learning content

Fig. 9 Research schedule (Anonymous 2012a). This figure shows the research schedule comprising the four research study stages: stage 1, day 1-involving the CSA screening test to allocate participants to their instructional treatment; stage 2, day 2-involving the pre-test for prior domain knowledge; stage 3, day 2 -involving the experiment; and stage 4 , day 2 -the post-test

Fig. 10 Cognitive performance of ICS groups with T1 and T2 (Anonymous 2012a). This figure shows the results in a graphical representation showing the interactive nature of the cognitive performance of integrated cognitive style (ICS) wholist-verbaliser, wholist-imager, analytic-verbaliser, analytic-imager for the two instructional treatments: $\mathrm{T1}$ (text-plus-textual metaphor) and T2 (text-plus-graphical format) based on average dlv

Fig. 11 Research schedule (Anonymous 2012a). This figure shows the research schedule comprising the four research study stages: stage 1, day 1-involving the CSA screening test to allocate participants to their instructional treatment; stage 2, day 2-involving the pre-test for prior domain knowledge; stage 3, day 2-involving the experiment; and stage 4, day 2 -the post-test
Fig. 6 Digital skills acquisition for introductory programming (McKay, 2000a p.175) This figure presents a 'test instrument specification matrix' used to design the test-items to determine the expected introductory programming knowledge acquisition.

Fig. 7 QUEST variable map (McKay, 2000a p.220) This figure shows how the QUEST estimate develops a uni-dimensional (logit) scale $(-3.0$ to 1.0) with equal intervals along each axis as it measures participants' performances and test-items together. The $x^{\prime}$ s on the left hand side of the figure represent an individual participant's performance with the total number of participants being 195. On the right hand side of the figure, is the difficulty rating of each test-item's performance (partial credit scored test-items have multiple entries: 8.1, 8.2 and 9.3, 20.2).

Fig. 8 QUEST fit map (McKay, 2000a p.222) This figure shows the fit statistics (listed horizontally .56 to 1.40 is the infit mean square); the asterisks represent the magnitude of the fit statistic for the test-item on the same line. The test-items that fall between the two vertical dotted lines (thresholds .77 to 1.30 ) are considered acceptable; test-items to the left overfit (see test-item 34), indicating duplication or having limited contribution. Underfit test-items to the right of the threshold lines, measure something else and need rewording.

Fig. 9 Relative distribution - 4-groups (McKay, 2000a p.235)

This figure shows the relative distribution of the four-instructional treatment/gender groups (Treatment-1 textual metaphor and Treatment-2 graphical metaphors). Females given the graphical metaphors achieved the highest post-test distribution. Females with the textual metaphor format had the lowest distribution. The two male groupings had similar distributions, resting between the two female distributions

Fig. 10 First screen of web-mediated instructional module (Mohamad, 2012 p.117)

This figure shows the opening web-mediated instructional system's screen display - including: how to navigate the instructional content and guidance on how to work through the instructional modules; (knowledge) navigation buttons or hyperlinks; and menu positioning relating to the current topic and learning content.

Fig. 11 Research schedule (Mohamad, 2012 p.104) This figure shows the Research Schedule comprising the four research study stages: Stage-1, Day-1 involving the CSA screening test to allocate participants to their instructional treatment; Stage-2, Day2 involving the pre-test for prior domain knowledge; Stage-3 Day-2 involving the experiment; and Stage-4 Day-2 the post-test. 
(Continued)

Fig. 12 Cognitive performance of ICS groups with T1 and T2 (Anonymous 2012a).

This figure shows the results in a graphical representation showing the interactive nature of the cognitive performance of integrated cognitive style (ICS) wholist-verbaliser, wholist-imager, analytic-verbaliser, analytic-imager for the two instructional treatments: $\mathrm{T}$ (text-plus-textual metaphor) and T2 (text-plus-graphical format) based on average dlv
Fig. 12 Cognitive performance of ICS groups with T1 and T2 (Mohamad, 2012 p.177)

This figure shows the results in a graphical representation of the interactive nature of the cognitive performance of integrated cognitive style (ICS) wholist-verbaliser, wholist-imager, analyticverbaliser, analytic-imager for the two instructional treatments: T1 (text-plus-textual metaphor) and T2 (text-plus-graphical format) based on average dlv.

\section{Anonymous information errors and corrections:}

\begin{tabular}{|c|c|c|c|}
\hline $\begin{array}{l}\text { Blinded citations upon } \\
\text { publication }\end{array}$ & $\begin{array}{l}\text { Blinded references upon } \\
\text { publication }\end{array}$ & $\begin{array}{l}\text { Unblinded citations upon } \\
\text { correcting }\end{array}$ & $\begin{array}{l}\text { Unblinded references } \\
\text { upon correcting }\end{array}$ \\
\hline Anonymous 1999a & $\begin{array}{l}\text { Anonymous (1999a). } \\
\text { Details omitted for } \\
\text { double-blind reviewing. }\end{array}$ & McKay 1999a & $\begin{array}{l}\text { McKay, E. (1999a). } \\
\text { Exploring the effect of } \\
\text { graphical metaphors on } \\
\text { the performance of } \\
\text { learning computer } \\
\text { programming concepts in } \\
\text { adult learners: A pilot } \\
\text { study. Educational } \\
\text { Psychology, 19(4), } \\
\text { 471-487. }\end{array}$ \\
\hline Anonymous 1999b & $\begin{array}{l}\text { Anonymous (1999b). } \\
\text { Details omitted for } \\
\text { double-blind reviewing. }\end{array}$ & McKay 1999b & $\begin{array}{l}\text { McKay, E. (1999b). An } \\
\text { investigation of text-based } \\
\text { instructional materials } \\
\text { enhanced with graphics. } \\
\text { Educational Psychology, } \\
\text { 19(3), 323-335. }\end{array}$ \\
\hline Anonymous 2000a & $\begin{array}{l}\text { Anonymous (2000a). } \\
\text { Details omitted for } \\
\text { double-blind reviewing. }\end{array}$ & McKay 2000a & $\begin{array}{l}\text { McKay, E. (2000a). } \\
\text { Instructional strategies } \\
\text { integrating the cognitive } \\
\text { style construct: A } \\
\text { meta-knowledge } \\
\text { processing model } \\
\text { (contextual components } \\
\text { that facilitate spatial/ } \\
\text { logical task performance). } \\
\text { Com. Sci. \& Info. Sys.(Ph. } \\
\text { D. thesis - Deakin } \\
\text { University, Geelong). }\end{array}$ \\
\hline Anonymous 2000b & $\begin{array}{l}\text { Anonymous (2000b). } \\
\text { Details omitted for } \\
\text { double-blind reviewing. }\end{array}$ & McKay 2000b & $\begin{array}{l}\text { McKay, E. (2000b). } \\
\text { Measurement of } \\
\text { Cognitive Performance in } \\
\text { Computer Programming } \\
\text { Concept Acquisition: } \\
\text { Interactive effects of } \\
\text { visual metaphors and the } \\
\text { cognitive style construct. } \\
\text { Journal of Applied } \\
\text { Measurement, 1(3), } \\
\text { 257-286. }\end{array}$ \\
\hline Anonymous 2008 & $\begin{array}{l}\text { Anonymous (2008). } \\
\text { Details omitted for } \\
\text { double-blind reviewing. }\end{array}$ & McKay 2008 & $\begin{array}{l}\text { McKay, E. (2008). The } \\
\text { Human-Dimensions of } \\
\text { Human-Computer } \\
\text { Interaction: Balancing the } \\
\text { HCI Eq. (1 ed. Vol. 3). } \\
\text { Amsterdam, Netherlands: } \\
\text { IOS Press. }\end{array}$ \\
\hline
\end{tabular}




\begin{tabular}{|c|c|c|c|}
\hline Anonymous 2012a & $\begin{array}{l}\text { Anonymous (2012a). } \\
\text { Details omitted for } \\
\text { double-blind reviewing. }\end{array}$ & Mohamad 2012 & $\begin{array}{l}\text { Mohamad, M. (2012). The } \\
\text { effects of Web-mediated } \\
\text { instructional strategies } \\
\text { and cognitive preferences } \\
\text { in the acquisition of } \\
\text { introductory programming } \\
\text { concepts: A Rasch model } \\
\text { approach. Doctoral Thesis } \\
\text { RMIT University, School of } \\
\text { Business Information } \\
\text { Technology and } \\
\text { Logistics, Melbourne. } \\
\text { https:/researchbank. } \\
\text { rmit.edu.au/view/rmit: } \\
\text { 160201/Mohamad.pdf }\end{array}$ \\
\hline Anonymous 2012b & $\begin{array}{l}\text { Anonymous (2012b). } \\
\text { Details omitted for } \\
\text { double-blind reviewing. }\end{array}$ & Alwi and McKay 2012 & $\begin{array}{l}\text { Alwi, A. \& McKay, E. } \\
\text { (2012). Consideration for } \\
\text { cognitive preferences to } \\
\text { enhance effective HCI in } \\
\text { online exhibits. } \\
\text { International Journal of } \\
\text { Computer Information } \\
\text { Systems and Industrial } \\
\text { Management } \\
\text { Applications (IJCISIM), } \\
\text { ISSN:2150-7988, 3, } \\
\text { 472-479. }\end{array}$ \\
\hline Anonymous 2015 & $\begin{array}{l}\text { Anonymous (2015). } \\
\text { Details omitted for } \\
\text { double-blind reviewing. }\end{array}$ & McKay and Izard 2015 & $\begin{array}{l}\text { McKay, E. \& Izard, J.F. } \\
\text { (2015, 21-23 July). } \\
\text { Evaluate online training } \\
\text { Effectiveness: Differentiate } \\
\text { what they do and do not } \\
\text { know. Paper presented at } \\
\text { the 8th International } \\
\text { Conference on ICT, } \\
\text { Society and Human } \\
\text { Beings } 2015 \text { (Multi } \\
\text { conference on computer } \\
\text { science and information } \\
\text { systems - MCCSIS), Las } \\
\text { Palmas de Gran Canaria. } \\
\text { 35-44. }\end{array}$ \\
\hline Anonymous 2016 & $\begin{array}{l}\text { Anonymous (2016). } \\
\text { Details omitted for } \\
\text { double-blind reviewing. }\end{array}$ & Barefah and McKay 2016 & $\begin{array}{l}\text { Barefah, A, \& McKay, E. } \\
\text { (2016). Evaluating the } \\
\text { design and development } \\
\text { of an adaptive e-Tutorial } \\
\text { module: A Rasch } \\
\text { measurement approach. } \\
\text { Paper presented at the } \\
\text { Educational Technologies } \\
2016 \text { (ICEduTech), RMIT } \\
\text { University, Melbourne. } \\
\text { https://eric.ed.gov/?id= } \\
\text { ED571591 }\end{array}$ \\
\hline
\end{tabular}

The publisher apologizes to the readers and authors for the inconvenience.

The original publication has been corrected. 
Author details

${ }^{1}$ RMIT University, School of Business Information Technology and Logistics, GPO Box 2476, Melbourne, Victoria 3000, Australia. ${ }^{2}$ Department of Engineering Education, Faculty of Technical and Vocational Education, Universiti Tun Hussein Onn Malaysia, 86400 Parit Raja, Batu Pahat, Johor, Malaysia.

Received: 7 June 2018 Accepted: 7 June 2018

Published online: 03 July 2018

Reference

McKay, E, \& Mohamad, MB. (2018). Research and Practice in Technology Enhanced Learning, 13(5). https://doi.org/10.1186/ s41039-018-0071-2. 